\title{
THE EFFECT OF SELF-LEARNING ON WORK CULTURE
}

\author{
Debora ${ }^{\text {a* }}$ \\ a* FKIP Universitas Palangka Raya \\ Jl. H.Timang Kampus Universitas Palangka Raya, Palangkaraya, Indonesia, debora@fkip.upr.ac.id
}

\begin{abstract}
The teacher is very crucial in a school with his/her competence. Especially, the teacher of tasks and roles can not be replaced even in today's technological era. Thus, the teacher must have a good self-learning that supports the competence and capacity as a teacher. Work culture can affect how a person's work. This work of people can not be separated from his/her capacity and competence. good working culture and ugly not be separated from one's selflearning.In this study was to investigate the effect of Self-Learning teacher's on Work Culture. The data were collected through participant observation using questionnaire with five options following Likert's Scale 1-5. The participants were 74 of teachers from 7 different vocational schools in Palangka Raya city. Using testing path analysis test to indicated the effect of Self-Learning Teachers' on Work Culture. Therefore, the self-learning teacher's to be important to increase student skills in her/his competence and mental of character that would affect on work culture.
\end{abstract}

Keywords: Competence, Self learning, Work Culture

\section{INTRODUCTION}

The problems faced by Indonesia at this time, especially with regard to education is closely related to mental attitude. A Sad phenomenon that occurs in the world of education with the events that occurred on teachers and students in the community, of course, an impact on the quality of education. As well as beating incident of teachers by parents or complaints by parents because of disciplinary actions that teachers do. How can education face these problems? Circumstances such as these events can not be dismissed, because any problems that occur, or an event that occurs is the circumstances that are related to one another. Therefore, the teacher as a key figure in teaching in schools must increase the potential associated with mental preparation through selflearning teachers.

Observing of the phenomenon in schools by learning it several times as visit to school toward the opportunity in order to guide the students to practice in field of experiences, find some things that also in concern (although not all schools so), where it appears to the teacher which assigns to the students, or go out of the classroom and did not return when time for giving lesson is over. But some teachers remain in the classroom, giving a task to be done, but let the students do the work without giving guidance to students. Sometimes school hours left empty because of the absence of the teacher in the classroom, even if based on the administration of teacher's absence and teacher's attendance with the attendance rate of $100 \%$ (because the attendance figures will affect the incentives that will be received by a teacher).

This research is already a lot of current on learning innovation which is then accompanied by changes in the curriculum. Learning that only emphasize the results sometimes make students desperate to targets that should be achieved. In fact, not only students who are depressed but also teachers, so the learning pattern never changed, even had demanded that teachers should be professionally marked with 4 (four) competence requirements that must be met. Studies of the learning model which is 
based on the theories of learning have also been a lot done, but the question is whether the research innovations such learning already achieved the expected objective in education in general in Indonesia? The development of innovation in learning initiated by education experts theoretically not wrong, but whether learning innovation has been fully internalized by teachers as a spearhead in the lesson?

The teachers as educators appreciation of the implementation of tasks and jobs that were the focus of the problem in this study. Efforts by the government to provide a teacher professional certificate still cannot achieve the objectives as foreseen in the professional title, as there are many teachers who have been certified as an educator was not much different from uncertified teachers. Why did it happen when they (teachers) a so-called professional for being already meet the requirements? We, of course, we do not necessarily accuse the teacher as the guilty party, because in education and learning, the teacher is only a part of a component of an educational system. There are still many more other components that can also affect the performance of teachers, one of which is the selflearning of teachers and work culture.

Teachers in the duties and roles need to live up to the role. That's why learning is closely related to the concept of self-teacher. Self-learning efforts of teachers are done by teachers consciously to always learn to improve the education quality... As one of the important components in the learning, the teacher must constantly make innovations in the learning accomplishments. Of course, self-learning teacher's not stand alone which can also depend on the teachers' work culture. The work culture that formed from the work habits of teachers in performing job duties. Habits in doing this work are also influenced by the teacher perspective in view and interpret the work and the state of her work. With the understanding of himself who encouraged him to study and explore the potential of myself as a teacher, it is expected to encourage their students. The results also revealed that there is a direct and positive influence between Self-learning and teacher performance. On the other hand, teacher's Self- learning did not have a direct influence on the behaviour of the leadership of a school principal. It means that a principal leadership behaviour actually does not bring a meaningful impact in developing his/her capacity as a teacher professional, but Selflearning does. Therefore, the teacher in his/her capacity building as a professional teacher can always be teaching oneself by self-learning. Capacity is building done by the teacher that influences teacher of performance, with this self-learning concept, can be used as a learning model applied by the teacher in practice lifelong learning concept, especially the vocational teacher in facing Masyarakat Economy Asian (MEA).

The research in self-learning on teacher's that indicated there is a direct influence of self-learning teacher with the teacher performance. Similarly, the research does not found directly affect of selflearning teachers on the behavior of school leadership. The teacher is one of the important components in the learning process in schools. Thus, the self-concept of teachers related to learning that is the decisive component which also appears in the work culture of teachers in the implementation of $n$ tasks and its role as a teacher. As well as research conducted by Eli Ginzberg (in Adi W.Gunawan, 2005) in the United States against the 342 study subjects who are graduates from various disciplines who received a scholarship from Columbia University who generally pass invitation pastas cum laude and summa cum laude, how successful life them after fifteen years out of education, gain, that there is no direct relationship between the academic and life success.

Theoretically, teacher's habits in teaching, called work - culture, related to individual and the habits of the group, found in an organization which also in a specific area. The work-culture in an organization for an employee, make them survive in their workplace as getting some good impact for a work conducive. The work culture also as could be related to the study of trust, the thinking process, the employee behavior, the ideology, and the principles in an organization. These will be as the cultures in an organization which will define how the employee could interact with each other, and how the function of an organization 
which then will be the work culture in the organization.

So then could be concluded that, the work-culture as a result of a view and visible practice in a work environment, how it can be managed in a good way by the society, especially in the workplace. Consider in ways how people looking for job, the work rhythm and the numbers of the unemployment in the workplace, a process how the relationship of a hierarchy, how the worker learn and manage their jobs, how they could be socialized and manage the living of their family, the Informal's worker behavior, how they could interact with the high authority. An organization which has good and positive work culture will have employees that following the organization rules, on the contrary, if the employees didn't follow the rules and just did them if there are tight procedures, and then this organization could be said having of the work cultures negative and weak. So, the behavior in working will describe the working behavior of each individual.So, the work culture as the behavior of the worker/employee will become habitual in an organization. The habits in a workplace are the result of the values, the beliefs, the norms, by the group or individual that will become the rules which will be obeyed by each individual as the member of an organization, in doing the activities in their workplace. These habits become the characteristics in doing their jobs or duties. So then, the work culture was the work habits which applied in an organization and followed by the members. The work culture itself followed by the members as the rules or norms, as the result of the view, also the behavior on the work activities, done by each member of the organization.

There has been a lot of research on self- regulated learning. Self-directed learning that is emphasized to one's ability to do or set goals, self-monitoring, selfinstruction, and self-reinforcement. So, here lies a person's ability to understand and control one's learning environment. Self-regulation as a process to develop mental ability into the skills possessed.(Zimmerman, Bonner, \& Kovach,2002; Schraw, Crippen, K., \& Hartley, (2006); Shunk, 1996; Paris, S \& Paris, A, 2001).

\section{A. Self-Learning}

The self-learning concept developed by a concept of learning and self-concept. According to Winfred F.Hill (2011:59) "Learning as an important thing which defines what are we and what are the activities we did..." as gave us a better understanding of the learning process. Actually, each individual has the process of learning within himself/herself, start from the birth, but the maturity of physic is not including in the learning process. So, learning itself refers to one's self-learning. Self - learning concept has a close relationship with the regulated self-learning, which has three components as well, they are, SelfObservation, Self-Judgment, and Self- Reaction. An individual which has an own judgment on himself/herself, also have done an evaluation of her/his work and will get a description for the next corrections that should be done on his/her own work. That is why self- learning needs a metacognitive concept, according to Baker \& Brown (1984) and Gagne (1993) in Kuntjojo, which are a cognitive knowledge, self-control mechanism, and cognitive monitoring. So then, the metacognitive could be defined as everything that we know already (as our knowledge) that we can regulate it in a behavior which is considered as the habits that we can learn.

Self-learning is directed more towards how a person can grow his mental attitude, so it can turn it into an attitude that supports self-regulated learning. Thus, self-learning refers more to self-assessment, selfimprovement agenda and self-reinforcement. In selfassessment includes how one is able to see the flaws and advantages that exist in him, so he can determine of the steps he takes to change his weakness and strength into self-strengthening. The three stages in self-learning are like a human life cycle that brings him toward lifelong learning. Therefore, lifelong learning is just a slogan if one can not do selflearning.

Veithzal Rival and Deddy Mulyadi (2009: 235) have defined that "learning as a relatively permanent change in behavior that occurs as a result of experience. The learning was meant as a change, if there is no change, means it has not been learning. Learning will indicate a shift away from someone 
who learns. At management context, these changes may be changes in negative and positive changes. People can learn good behaviors, but also can learn bad behaviors. In addition, in the context of learning itself, it is the nature of learning in related to the change, it can be the permanent change or can't be permanent, but it can also change that is not fixed. Thus, it can be said that the modification of behavior can be done through a study. Learning also about someone mindset which will become a habit or behavior that supporting an individual or organization in making some acts.

Thus, self-learning refers more to selfassessment, self-improvement agenda and selfreinforcement. In self-assessment includes how one is able to see the flaws and advantages that exist in him, so he can determine of the steps he takes to change his weakness and strength into self-strengthening. The three stages in self-learning are like a human life cycle that brings him toward lifelong learning. Therefore, lifelong learning is just a slogan if one can not do selflearning.

\section{B. Work Culture}

The work culture that reflects the specifications of the work in an organization, we must first interpret itself the nature of the work. According to Nana Fattah, work is an act of doing things and the people who work there is to do with making a living or aiming to get rewarded for achievements that have been given over the interests of the organization. While Andrias Harefa, defines work as an activity or activity that is planned to run life and life outwardly, mental, social and spiritual. Further mentioned dimensions of work, namely are social dimension (associate, life in unity, and touch), mental (learning, self-actualization), and spiritual (religious).

So, in essence, the people were worked to do an activity to meet their needs. So, this requirement is an encouragement for people to do the work. At this sense implies that people who work have encouraged her motivation as a basis for doing the work. Certainly, boost the employment differ between one individual to another individual. Differences of
Work motivation or encouragement of such work can be reflected in the behavior of the displayed work.

According to by Herry Tjahjono (2011:77), an organizational culture and work culture has several properties as follows: 1) The culture is dynamic, 2) Culture can be formed intentionally or not, then we can build and develop a culture that we want or expect, and 3) Culture was on the level of implementation, requires a total commitment of top management.

Work culture was important for an employee in an organization that allows them to survive in the organization, so organizations have to create a work environment conducive. The culture was referred to as the concept of work related to the study beliefs, thought processes, employee attitudes, ideology, and principles of this organization. Thus, an organizational culture that determines how employees interact with each other, and how they were function and their organization into the work culture within the organization. At Work Culture Meaning, Importance, and Characteristics of a Healthy Culture explained mention characters of culture following a healthy work.

A healthy work culture leads to satisfied employees and increased productivity, 2) employees must be cordial with each other, 3 ) each employee should be treated as one, 4) appealing the top performers is important, 5) encourage discussions at the workplace, 6) organization must have employee friendly policies and practical guidelines, 7) the "hitler approach" does not fit in the current scenario, 8) promote team building activities to bind the employees together. (Management Study Guide, April 2, 2012).

From the studied theoretical can be understood that the culture as a pattern of behavior becomes a habit in an organization. These are habits of the result a values, beliefs, norms adopted by groups and individuals to become rules obeyed by the individual as a member of the organization for doing his or her job in the organization. The habits prevailing in the organization are held by individuals or groups become characteristic in performing job duties. 
Therefore of work culture was a work habit applied to an organization that is held by each of its members as rules or norms, which are the result of the views, and attitudes toward work-related activities within an organization.

The indicators of the Work culture are: 1) the view of Work; 2) the principles of work; 3) The Orientation of Work priorities; 4) The Job of Values Orientation; 5) The Work of orientation; 6) the work norms and regulations; 7) Use of technology (work); 8) Work troubleshooting; 9) Giving recognition of work performance

\section{METHODS}

The method research used survey method with quantitative approach. In this study was used a technique of path analysis to get the effect of selflearning on culture work of teacher. Data collection was used questionnaire instrument model Likert's 15. The population was vocational teachers from 7 schools (276 people) in Palangka Raya city and to get samples (74) were used Slovin's formula, it's a random sampling technique (Cochran, W,1977, ; Kish, L,1965.).

Assessment Instrument culture work using a rating scale (rating scale) with alternative answers, that is: has always, often, fairly often, rarely and had never. The alternative answers are given weight value five to one for a positive statement and the weight value of one to five to negative statements. Culture work of instrument uses questionnaire consisting of 27 grains of the item. Thereby hence the theoretical range of scores between 56 and 125 . The validity of Culture work to conducted with the aid of Microsoft Excel computer software. The validity of each item the declared valid if value rhitung $>$ table. Nilai table for $n=27, \alpha=0.05$ is equal to 0,3172 . From 27 grains of items, which deciduous 6 grains of items, so it was used for research, were 27 items Cronbach's $\alpha=0.945$.

The validity of the instrument of self-learning, of 25 grains of items based on a calculation of all valid, the reliability of the instrument, Cronbach $\alpha=$ 0.953. Instrument self-learning of 26 grains of items, only 1 (one) point items that are not valid and should be dropped, so that the reliability of the instrument grain item Self-Learning as much as 25 of the questions, then obtained a Cronbach $\alpha=0.79$.

Statistical Analyses. First, The requirements analysis test including normality test and significance tests performed prior to testing hypotheses with the regression linearity. An error distribution normality test by using tests Lilies. Terms fault is if the statistical test, $\mathrm{L} 0<\mathrm{L}$ table $(\alpha=$ 0.05 ), then the data are normally distributed. But when L0 > L table, the data were not normally distributed. The Significance Tests of Coefficient Linearity of Regression and correlation. Second, Subsequent analyses conducted to examine the relationship of between independent variables and dependent variable correlation analysis and the testing of linearity and the significant testing with the regression equation, the final analysis is done by calculating linear equations using a correlation coefficient to find the value of the coefficient of determinant, which shows the influence of variables. Structural model of the in this research presented again like seen in Figure 1. In this study, the pathways analysis models that are used is recursive models (model one way) then the path coefficient using simple correlation coefficient. The path coefficients or the regression coefficient is equivalent to the beta coefficient. The Path coefficient calculation using SPSS software version 19

\section{RESULTS AND DISCUSSION}

\section{A. Result}

Based on calculations of Work- culture variable obtained through a questionnaire that work culture to 74 teachers working in seven vocational schools in the city of Palangkaraya, the empirical of data obtained as follows: the lowest of score (minimum) 65; And the highest score of (maximum) 125; Total score of 7210, mean 97,432, mode (Mode) of 100.00; and Standard deviation of 14,511. See table 1. Based on these results, we can conclude that the trend of 
teachers' work culture at seven (7) state of vocational school in the town of Palangkaraya in carrying out duties in good and excellent categories.

Based on the result of Self-Learning calculation obtained through questionnaires to 74 teachers at 7 public vocational schools in Palangka Raya city, the empirical data are as follows: lowest score (minimum) of 75; And the highest score (maximum) of 125; Total score 7632, mode of 100; Standard deviation of 10.786. See table 2. Based on these results, it can be concluded that the trend of SelfLearning teachers at 7 (seven) public vocational high schools in the city of Palangka Raya in carrying out the tasks on the category of good and very good.

Test Normality data Score Estimated Error SelfLearning Values on Working Culture (X over Y). Based on the calculation results obtained value LO, highest Lcount $=0.071$. Value is smaller than the value in table $(\mathrm{n}=74$ and $\alpha=0,05)=0,103$ and at Ltable $(\alpha=0,01)=0,1178$. (Thus it can be argued that the distribution of Self-Learning (X) errors over Working of Culture (Y) comes from a normally distributed population.

Table 1. Frequency Distribution of Work Culture

\begin{tabular}{ccccc}
\hline $\begin{array}{c}\text { Score } \\
\text { No }\end{array}$ & $\begin{array}{c}\text { Class } \\
\text { Interval }\end{array}$ & $\begin{array}{c}\text { Absolute } \\
\text { Frequency } \\
\text { (f) }\end{array}$ & $\begin{array}{c}\text { Relatif } \\
\text { Freque } \\
\text { ncy (\%) }\end{array}$ & $\begin{array}{c}\text { Cumula } \\
\text { tive } \\
\text { Freque } \\
\text { ncy (\%) }\end{array}$ \\
\hline 1 & $65-73$ & 2 & 2,7 & 2,7 \\
2 & $74-82$ & 10 & 13,5 & 16,2 \\
3 & $83-92$ & 12 & 16,2 & 32,4 \\
4 & $93-101$ & 15 & 21 & 53,4 \\
5 & $102-110$ & 18 & 24,3 & 77,7 \\
6 & $111-119$ & 9 & 12,6 & 90,2 \\
7 & $120-128$ & 8 & 10,80 & 100,00 \\
& Total & 74 & 100,00 & \\
\hline
\end{tabular}

Table 2. Frequency Distribution of SelfLearning Score

\begin{tabular}{ccccc}
\hline No & $\begin{array}{c}\text { Class } \\
\text { Interval }\end{array}$ & $\begin{array}{c}\text { Absolute } \\
\text { Frequenc } \\
\mathbf{y}(\mathbf{f})\end{array}$ & $\begin{array}{c}\text { Relatif } \\
\text { Frequenc } \\
\mathbf{y}(\boldsymbol{\%})\end{array}$ & $\begin{array}{c}\text { Cumula } \\
\text { tive } \\
\text { Freque } \\
\text { ncy (\%) }\end{array}$ \\
\hline 1 & $75-81$ & 4 & 5,4 & 5,4 \\
2 & $82-89$ & 4 & 5,4 & 10,8 \\
3 & $90-97$ & 6 & 8,12 & 18,92 \\
4 & $98-105$ & 25 & 33,78 & 52,7 \\
5 & $106-113$ & 24 & 32,43 & 85,13 \\
6 & $114-121$ & 10 & 13,51 & 98,64 \\
7 & $122-126$ & 1 & 1,35 & 100,00 \\
& Total & 74 & 100,00 & \\
\hline
\end{tabular}

TABEL 3 ANAVA for Significance and Linearity

$\mathrm{Y}=82,552+0,1857 \mathrm{X}$

\begin{tabular}{|c|c|c|c|c|c|c|}
\hline \multirow{2}{*}{$\begin{array}{c}\text { Source } \\
\text { of } \\
\text { Variati } \\
\text { on }\end{array}$} & \multirow[t]{2}{*}{ Df } & \multirow{2}{*}{$\begin{array}{c}\text { Sum of } \\
\text { Squares }\end{array}$} & \multirow{2}{*}{$\begin{array}{c}\text { Avarag } \\
\text { e } \\
\text { Numbe } \\
\text { r of } \\
\text { Squares } \\
\end{array}$} & \multirow[t]{2}{*}{$F_{\text {count }}$} & \multicolumn{2}{|l|}{$F_{\text {table }}$} \\
\hline & & & & & $\begin{array}{c}\alpha= \\
0,05\end{array}$ & $\begin{array}{c}\alpha= \\
0,01\end{array}$ \\
\hline Total & 74 & 795620 & & & & \\
\hline $\operatorname{Reg}(\mathrm{a})$ & 1 & 787127 & 787127 & & & \\
\hline $\begin{array}{l}\text { Reg } \\
\text { (b/a) }\end{array}$ & 1 & 423,95 & 423,95 & $\begin{array}{c}3,783 \\
1\end{array}$ & 3,96 & $\begin{array}{c}7,, 0 \\
1\end{array}$ \\
\hline $\begin{array}{c}\text { Residua } \\
1\end{array}$ & 72 & 423,95 & 112,07 & & & \\
\hline $\begin{array}{c}\text { Tuna } \\
\text { fit }\end{array}$ & 36 & -8177 & $-170,4$ & $-0,694$ & 1,88 & 2,47 \\
\hline Error & 36 & $\begin{array}{c}26342,6 \\
8\end{array}$ & 731,74 & & & \\
\hline
\end{tabular}

Significance and Linearity of Self-Learning (X) on Work Culture (Y After the calculation of significance test and linearity Self-Learning (X) on Work Culture (Y) yield regression equation $\mathrm{Y}=82,552+0,1857 \mathrm{X}$. The result of variance analysis (ANAVA) on this model is shown in Table 3

Inferential statistics of the results of calculations used testing path analysis test (py) amounted at $0.425, \mathrm{t}=$ 3.870 , at $\alpha=0.05$, obtained table $=1.671$, for 3,870 $>1,671$ means of these findings are interpreted positive direct the effect of Self learning teacher's on Work culture. 


\section{B. Discussion}

From these findings were interpreted positively influence culture Work towards Self-Learning teacher. In the concept of work culture and selflearning is part of the theory of organizational behavior. Work culture is to affects the way people act in the organization. How they work and see the future which is largely determined by cultural norms, values, and beliefs (Thomas and Kerr Inkson, 2004: 22). These were experts in Organizational Behavior it often uses the concept of culture to explain the phenomenon of groups, including the phenomenon of an organization. The study is known as the concept of organizational culture.

To according by Tjahjono (2011:77), the culture was should basically be taught, learned, developed, socialized, internalized and used as a guide through the existing values. In harmony with the opinion of Hodge and Anthony (1991: 699), its defines culture as "the sum total and the characteristics of the typical traits learned the behavior of members of society, values, norms, artifacts and behavior patterns are recognized by a society. Koentjaraningrat (1980:180). Which defines culture as "the whole system of ideas, actions and man's work in the context of a society that made the property of the man with the" learning ". Meanwhile, Schein (1997: 12) reveals, that culture was "a pattern of basic assumptions invented and developed by a given group as study and master the problem external adaptation and internal integration", which has worked well enough to be considered viable and therefore taught to new members as a way perceived, as well as thinking perceived correctly in relation to an issue. Meanwhile, work is an act of doing things and the people who work there is to do with making a living or aiming to get rewarded for achievements that have been given over the interests of the organization as well as the activity or activities planned for run life and life outwardly, mental, social and spiritual. Further mentioned dimensions of work, namely were social dimension (associate, life humanity, touch), mental (learning, selfactualization), and spiritual (Fattah, 2003: 19; and Harefa, 2004: 31).

So, the activity do was to meet need peoples. That's requirement was an encouragement for people to do the work. At this sense implies that people who work have encouraged her motivation as a basis for doing the work. Certainly, boost the employment differ between one individual to another individual. Differences in work motivation or encouragement of such work can be reflected in the behavior of the displayed work. But basically, the motivation process is largely geared to meet and reach requirements. Thus, work culture or a culture of work it's a work habit by individuals in a workplace that is affected by the view or a prevailing belief in the organization of work.

Self-learning was an essentially the learning applies to adults who already have a concept of self or selfmaturity who have understood the purpose of what it does. Learning aimed at adults who have had experiences that made one of the bases for developing his/her potential also experience acquired skills through self-learning conduct expected some changes towards more good.

To change it's that the keyword of the learning and there was not a success in life if peoples were not studying or in other words do not do self-learning. Self-learning is self-consciousness of the man who can see who she was or in other words has the selfconcept. Who understand the truth and know what is required by you in order to succeed. To achievement or good work cannot be separated from learning, especially learning undertaken by you.

Work culture was displayed by teachers in achieving the quality of education was based also on the attitude displayed by the teacher who can be said to be influenced by factors of the teachers themselves. The 


\section{Debora. / Journal of Educational Administration Research and Review/Vol. 01 No 1 June 2017}

several was factors that effect on teachers' work culture in the organization of the school with all the responsibility of the teacher as an educator, as well as administrative tasks, were the variable self-learning or self-learning. Self-learning was the result of selfmotivation is on the teacher to constantly develop themselves in any form in order to achieve self-ability was not out of self-concept of the teacher as the beliefs, views or judgment, feelings and thoughts individual against himself covering ability, character, and attitude of the individual.

Based on the core self-learning, namely one's mindset in looking at him that wants to be grown in a sense never satisfied to learn, and this will be manifested in the work. Thereby to produce good work need to have the ability and skills that are the dimension of a performance or anything resulting from the work, which is influenced by the presence of a healthy work culture.

From the research to results proved that the teacher has a high work culture to form a self-learning. High working on culture what was direct to be fostered by the principal in accordance with the results of hypothesis testing in this study that shows that the behavior of the leadership of a positive direct impact on the work culture.

Work culture was displayed by teachers in achieving the quality of education was based also on the attitude displayed by the teacher who can be said to be influenced by factors of the teachers themselves. The several was factors that effect on teachers' work culture in the organization of the school with all the responsibility of the teacher as an educator, as well as administrative tasks, were the variable self-learning or self-learning. Self-learning was the result of selfmotivation is on the teacher to constantly develop themselves in any form in order to achieve self-ability was not out of self-concept of the teacher as the beliefs, views or judgment, feelings and thoughts individual against himself covering ability, character, and attitude of the individual.

Based on the core self-learning, namely one's mindset in looking at him that wants to be grown in a sense never satisfied to learn, and this will be manifested in the work. Thereby to produce good work need to have the ability and skills that are the dimension of a performance or anything resulting from the work, which is influenced by the presence of a healthy work culture.

From the research to results proved that the teacher has a high work culture to form a self-learning. High working on culture what was direct to be fostered by the principal in accordance with the results of hypothesis testing in this study that shows that the behavior of the leadership of a positive direct impact on the work culture.

To the formation of the work culture that depends on the self-concept of the individual. The work environment in the form of culture serves to establish how to behavior of the work done by the individual. Because of the behavior of individuals, forming an organizational behavior that can be positive or negative. While the self-learning by individuals closely associated with the positive values of the individuals that make up an individual's behavior, which too became, in turn, the culture of the individual.

The teacher that related to the duties and role to facing the challenges and global competition will force to the "competed" in the sense of positive competition. The teacher that related to the duties and role to facing the challenges and global competition will force to the "competed" in the sense of positive competition. The teacher that related to the duties and role to facing the challenges and global competition will force to the "competed" in the sense of positive competition. It is indispensable for the human resources that are 
reliable and qualified. If the establishment is charged to the education of human resources, the education must be able to form its quality and powerful force. The teacher as one of the academic staff responsible for the challenges and the global competition. How do teachers playing the challenges of the roles and duties as educators? For that teacher themselves are required and are responsible for his proposition through his roles with the establishment of a positive work culture in a sense reflects their professionalism as an educator with 4 (four) competencies with awareness to have a high of self-learning. The teacher that related to the duties and role to facing the challenges and global competition will force to the "competed" in the sense of positive competition. The teacher that related to the duties and role to facing the challenges and global competition will force to the "competed" in the sense of positive competition. The teacher that related to the duties and role to facing the challenges and global competition will force to the "competed" in the sense of positive competition. It is indispensable for the human resources that are reliable and qualified. If the establishment is charged to the education of human resources, the education must be able to form its quality and powerful force. The teacher as one of the academic staff responsible for the challenges and the global competition. How do teachers playing the challenges of the roles and duties as educators? For that teacher themselves are required and are responsible for his proposition through his roles with the establishment of a positive work culture in a sense reflects their professionalism as an educator with 4 (four) competencies with awareness to have a high of self-learning.Teacher must always be developed on Potential or capacity with no effort his or her learning. Learning self has made teachers whose direction to increases the capacity or potential. To increase capacity, it makes the teacher as a creative individual. Creativity of the teacher will be able to form teachers to create a positive on work culture with the creation of a school environment that is conducive to learning. Besides, the independence of teachers in action learning also supports the establishment on work culture teacher, which will ultimately learning formed of culture learners. For a teacher that directly deal with students in the classroom.

Many concepts of learning that should be actualized teacher in the classroom to develop the potential of learners. Teachers must have the creativity and daring test piloted each of the concepts of learning correctly, do not to avoid mistakes such as the existence of some research findings about no way psychomotor process of learning strategies and the Student Learning active as a result of misinterpretation of articulation and actualization in the field, based on "instruction "and" decisions "with the concept that it should.

Thus, the teacher as an individual requires a positive self-learning in order to establish a positive work culture. of behavior, forming an organizational behavior that can be positive or negative. While the self-learning by individuals closely associated with the positive values of the individuals that make up an individual's behavior, which became the culture in turn of the work of individual do not an absolute. Culture an inheritance, work culture is a choice, and therefore there should be a change (transformation) on work culture. Here, the role of self-learning on the transformation of work culture.

\section{CONCLUSION/RECOMENDATION}

Finding to affect Teacher Self-Learning is positive on Work culture. That is, every teacher in Government Vocational high School in Palangkaraya city who open themselves to receive constructive criticism against him in a sense have the self-assessment as well as the desire to always learn to fix what is lacking in him and has motivation to learn from experiences, both from within him and outside the member himself will direct positive effect on the performance of teachers. 
Debora. / Journal of Educational Administration Research and Review/Vol. 01 No 1 June 2017

There will be an increase in teacher performance has implications for the 4 (four) competencies required of professional teachers as educators as to said in 14Law number, 2005 at 20 page Article, paragraph $\mathrm{b}$, with one of which have to develop competence in a sustainable manner. To give emphasis to the importance of teachers to do self-learning that impact innovation in the classroom.

Thus, teachers were expected to develop their potential with never to stop learning. The concept of lifelong learning does not only used as a slogan alone, but accompanied by positive action to be always for learning.

\section{REFERENCES}

[1] Brown, B.B, (11 Pebruari 2012), Employees Organizational Commitment and Their Perception of Supervisors Relation-Oriented Leadership Behaviors, (2003) : www.emerldinsight.com/0953-4814,htm.

[2] Cochran,W,1977, Sampling Technique 3 rd Ed, Newyork: John Wiley and Sons, Inc

[3] Fattah, N, (2003) Landasan manajemen Pendidikan, Bandung : Penerbit PT Remaja Rosdakarya.

[4] Furnham, A, (2005) The Psychologi of Behavior At Work The Individual in The Organization Second Edition, New York: Psychologi Press.

[5] Harefa, A, (2004), Membangkitkan Etos Profesionalisme, Jakarta : Gramedia Pustaka Utama.

[6] Hodge,B.J, and Anthony, Willia P. (1991), Organization Theory, Boston: Allyn and Bacon.

[7] Hill, F, Winfred, (2011), Theories of Learning. Terjemahan, Cetakan V, Bandung : Penerbit Nusa Media.

[8] Koentjaraningrat, (1982), Kebudayaan Mentalitas dan Pembangunan, Jakarta : PT. Gramedia

[9] Kuntjojo, (6 Mei 2012), Metakognisi dan Keberhasilan BelajarPeserta Didik, http :// ebekunt, wordpress.com /2009/14/12/metakognisi- dan- keberhasilan belajarpeserta-didik/ html.

[10] Kish, L,19654 Survey Sampling, New York: John Wiley and Sons, Inc.

[11] Kreitner, Robert dan Angelo Kinicki, (2005), Organizational Behavior, (terjemahan),Jakarta: Penerbit Salemba Empat.

[12] Lynn Y. Weiner, (22 April 2012), The Electronic Encyclopedia of Chicago (C) 2005 Chicago Historical Society.(The Encyclopedia of Chicago (C) 2004 The Newberry

Library), http://www.encyclopedia.chicagohistory.org/pages/1382.h tml.

[13] Management Study Guide, ((April 2, 2012) Work Culture - Meaning, Importance \& Characterics of Healthy Culture;http://www.managementstudyguide.com/workculture.htm

[14] Paris, S \& Paris, A, (2001). Classroom applications of research on self-regulated learning. Educational Psychology, 36, 89-101.

[15] Rivai, Veithzal, Murni, Sylviana,( 2009) Education Management Analisis Teori dan Praktik,Jakarta: Rajawali Pers.

[16] Schraw, Crippen, K., \& Hartley, (2006). Promoting self-regulation in science education: metacognition as part of a broader perspective on learning. Research in Science Education, 36, 111-139.

[17] Shunk, D. (1996). Goal and self-evaluative influences during children's cognitive skill learning. American Educational Research Journal, 33, 359-382.

[18] Schein ,Edgar. (1997), Organizational Culture and Leadership, San Francisco:Jossey-Bass.

[19] Tjahyono, Herry, (2011), Culture Based Leadership, Jakarta: PT Gramedia Pustaka Utama.

[20] Thomas, C, David dan Kerr Inkson, (2004), Cultural Intelligence, San Francisco: Barret-Koehleer Publisher, Inc.

[21] Zimmerman, B., Bonner, S., \& Kovach, R (2002). Developing self-regulated learner; Beyond achievement to self-efficacy. Washington DC: American Psychological Association. 